\title{
Fighting COVID-19 in Nigeria: Leadership and collaboration in Numbers 12:9-16
}

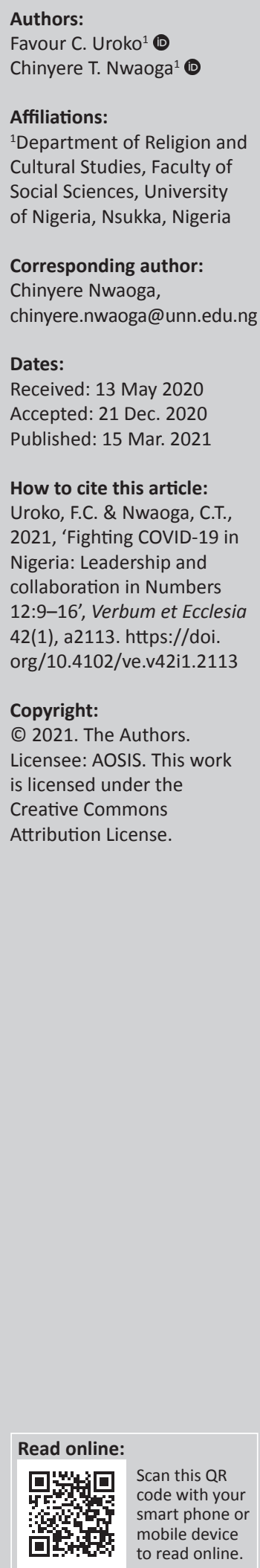

Numbers 12:9-16 deals with a situation that deserves an urgent response. It defines leadership and collaboration in the period of crisis. The pericope provides roadmaps on how Nigerians can tackle the contemporary coronavirus disease 2019 (COVID-19) pandemic in Nigeria. Miriam was struck with an incurable illness from God. Moses, with his leadership skills, was able to consult God, who insisted that Miriam be isolated and quarantined for seven days to prevent an escalation of the infectious disease. Using the narrative analysis, the study demonstrates that Moses' display of transparent and systematic profiling, effective leadership and collaboration of all Israelites helped to curb the pandemic from escalating. Having observed this phenomenon, the researcher believes that the pericope will speak anew to the current fight against the coronavirus pandemic in Nigeria. Findings reveal that infective leadership and collaboration led to increased poverty, insecurity and domestic abuse in Nigeria during the coronavirus era.

Intradisciplinary and/or interdisciplinary implications: The research is based on the rising cases of the coronavirus in Nigeria. It was discovered that a lack of transparency, a lack of leadership, and civil disobedience are the major factors causing a failure in the fight against the COVID-19 pandemic in Nigeria. Disciplines implicated include Sociology, Old Testament and Dogmatics.

Keywords: COVID-19; Numbers 12:9-16; coronavirus; isolation; quarantine; lockdown.

\section{Introduction}

On 17 April 2020, Nigeria's most powerful politician and the president's right-hand man, Abba Kyari died from coronavirus disease 2019 (COVID-19). In Kano state, over 100 people are reported to have died due to the COVID-19 pandemic in April 2020 (Izundu 2020:1). The government of Nigeria has done so many things, and also took steps to curtail these growing deaths by COVID-19. However, the situation continues to worsen. Unfortunately, at the beginning of May 2020, Nigeria had over 3000 COVID-19 cases and more than 100 deaths with most cases found in the country's busy commercial capital Lagos, Kano and the federal government capital, Abuja (Amaza 2020:1). The government promulgated laws to halt human and vehicular movements, but unfortunately, security agencies liaised with the citizens to circumvent these measures put in place by the government of Nigeria. Worst still, the almajiri children in northern Nigeria became a medium for the widespread distribution of COVID-19 in Nigeria. The almajiri are children in northern Nigeria whose parents have abandoned and left them to struggle and care for themselves; supporting Mallams - who use them for crime and violence in the streets, whilst others are lost to disease and hunger (Nwanze 2019). The almajiri are transported from state to state without safety measures. For instance, 14 almajiri children from Kano (Enyiocha 2020), five almajiri children in Kaduna (Folarin 2020) and 16 almajiri children in Jigawa tested positive for COVID-19 in April 2020. On a daily basis, people being infected by the virus keep rising in Nigeria. Having observed this development, the researcher believes Numbers 12:9-16 to be relevant in Nigeria's coronavirus-prone environment.

A close observation of Numbers 12:9-16 reveals that it vividly illustrates the process of isolation, lockdown, and quarantine, which are essential for COVID-19 control. In the Bible, Miriam was afflicted and declared as unclean, she was barred from the camp for seven days; therefore, as a consequence, meeting her was a taboo for a space of time corresponding to the isolation period according to Levitical law (Mcewen 1911:258). The people were confused, wondering what they should do for her to recover and to contain the disease from spreading. How the Israelites were able to resolve this crisis in those times is of theological significance to the present Nigerian leaders and their followers. In the pericope, Miriam's disease was considered communicable (Lewis 1987:593-612). Gould (2005:13) attested that lepers were thought to threaten the society and that is why they were separated from other Israelites. 
Recent scholars have highlighted the Bible's standpoints on pandemics. Noth (1968:92) says that Numbers 12:9-16 concerns skill disease caused by rebellion. Alexander and Baker (2003:569) clearly say that Numbers 12 refer to Miriam and Aaron's challenge of Moses' leadership and their subsequent punishment. Hale (2007:355) explains that Numbers 12:9-16 concerns the people of Israel, who placed their migration on hold because of the infectious nature of Miriam's disease. Boniface-Malle (2006:171) aptly puts that Numbers 12:9-16 is an illustration of leadership in a period of health challenges. He views the theological import of the pericope as an emphasis on Moses' prestige, authority, modern leadership thoughts, spirituality and practical wisdom (Boniface-Malle 2006:171). Numbers 12:9-16 has been used by scholars to show 'the dominating thought of a demonstration of God's power by a sudden and stroke-like miracle on Miriam' (Gieniusz 2013; Mcewen 1911; Robinson 1989). Finding literature on the social ethics of isolation and lockdown in the periscope which was needed during the period of pandemics is rare. It is on this basis that social ethics in Numbers 12:9-16 will be used as the spotlight in finding solutions to the rising coronavirus infections in Nigeria.

Using the narrative analysis, the study investigates how the morals, values and beliefs of Moses, Miriam and the people of Israel interact with each other to create a holistic view of the pandemic. Tushima (2018:1) notes that to a large degree, this is the reason for narratives to rest in the actions and inactions of characters. In order to derive the theological significance and relevance from narratives, proper attention has to be paid to the characters in the Numbers 12:9-16. In this light, it is interesting to go beyond the confines of the narrative structures and attempt to locate all the relevant themes in the pericope, with the help of a literal analysis, to weave these themes into a point of reference that can warn and sustain Nigerians during this period of COVID-19.

\section{The historical and literary context of Numbers 12:9-16}

The Old Testament is replete with pandemics (Ex 8, 9:9, 12:12). It was in the course of these pandemics that the ancient Israelites and the neighbouring people searched for the significance of their misfortunes; often realising that pandemics happen for a reason and lessons must be learnt in anarchic and tumultuous situations. Routledge (2008:311) reveals that the pandemic in Egypt was an act of God's providence ordering and overruling human affairs. The Egyptian experience of pandemics described in the Hebrew Bible specifically, enunciated a terrible warning in fulfilment of God's promise to Abram and formed the bedrock of new regulations (Ndjerareou 2006:102-103).

Throughout the period of migration to Israel through foreign lands, the cause of any disease was addressed by performing a ritual, rather than finding a medical cure. One may not have control over their fate, but rituals offered some sense of security in the midst of catastrophes (Tervanotko 2020). Most of the rituals described in the Bible are under the charge of various classes of priests (Lv 7:28-34). The Hebrew Bible gives scattered information about rituals in ancient Israel, because the priests who codified the ritual regulations of the Torah were understandably more interested in only those rituals in which they themselves played a primary role (Coogan 2008:65). Some offerings were made to remedy 'uncleanness' or ritual impurity, which may have been caused by disease, and so the priests functioned as healthcare providers as well (Coogan 2008:66). It is also important to mention that the priests in ancient Israel were in charge of resolving legal issues, where divination was used to interpret the divine will.

Ancient Israel and surrounding nations have always searched for meaning in their misfortunes during pandemics. Israel found out their misfortunes in Numbers 21 was God's response to their sin of blasphemy. Israelites knew that pandemics happen for a reason and the lessons imparted through them are important to prevent future occurrences. Moses used the snake as a healing medium based on the recommendation of God. Milgrom (1990a:459) says that snakes were associated with healing in various societies throughout history. This indicate that the people of the ancient near east were acquainted with the use of snake bites and snakes to find a solution to the cause of a pandemic.

Another important aspect has to do with the compositional history of the pericope. The book of Numbers is believed to be written by Moses. This book chronicles the movements of the Israelites in their journey through the Wilderness of Sinai. Numbers describes the journey in the wilderness, which can be a powerful metaphor for individuals and communities who face a kind of exile (Bellinger 2012). The central characters are Moses, Miriam, Aaron, Joshua, Eliad and Medad whilst the supporting characters comprise the vast majority of Israelites. In the narrative, the people of Israel complained to Moses about the lack of food as they did in Egypt, which evoked God's displeasure. Moses complained to God that he was tired of the complaints of the Israelites. According to Reis, Moses' appeal to God for amelioration serves the anxious moment three ways. Firstly, it redirects God's attention from perilous concentration on the people to sympathetic consideration of Moses. Secondly, it provides a cover story under which Moses can represent the dissidents as suckling infants; perhaps God's rancour will be supplanted by parental affection and forbearance. Thirdly, if the children of Israel, swayed by the riffraff, so quickly and easily turn from their Lord and redeemer, then more localised leadership is required to keep them on the straight and narrow. In contemporary times, people create their own responses to cope with the unknown during a misfortune or times of crises. It is in keeping with this line of thought that Professor Tervanotko declares that 'recognising this human need to rationalise crisis helps us to understand various explanations that people continue to give for the pandemic' (Tervanotko 2020:1). 
The literary context is also important. Whilst Numbers 12:1-16 technically are a stand-alone narrative, they exist within the larger context of the narratives directly before and after, and to a lesser extent all the narratives of the wilderness, to show descendants of Israel how God was cleaning house from the generation of Exodus to the generation allowed to enter the Promised Land in Joshua (Robern 2012:7). It occurs with the divisions in the history of Israel (Num 1-4 [histories of numbering], 7-8 [dedication of altar and Levites], 9-10 [their trooping], 11-14 [their murmuring, unbelief and the infectious disease on Miriam], 16-17 [rebellion of Korah], 20-26 [History of the last year], 31-32 [the conquest of Midian], and Chapter 33[history of their journeys]). The underlying theme of this division is the covenant between God and Israel (Hale 2007:334). The first subsection, 10:11-36, focuses on Yahweh's leadership as the people move from Sinai to Paran. The people move as an organised tribal unit and there is no reference to failures, needs, difficulties or God's judgments (Boniface-Malle 2006:171). This indicated that the people were respectful, humble and faithful to the God of their ancestors. Unfortunately, this fine picture began to fade. In the second section (Chapter 12), the people complained about hardships in the desert and took part in a series of rebellions against God, as well as their leaders. The rebellions were often followed by God's judgment, Moses' intervention and God's mercy and forgiveness (Boniface-Malle 2006:171). This rebellion escalated to the point that even the leaders of Israel were involved in a rebellion against God. Miriam bore the brunt of the crisis because God infected her with a skin disease which forced the Israelite to isolate her and Israel as a nation was under a lockdown until a solution to the sickness could be found. Noth (1972:182) reveals that Miriam stood out as a powerful and meaningful historical figure.

The message revealed in this text has much to convey in the present coronavirus pandemic ravaging Nigeria. Citizens and leadership failures are present in Nigeria today just as they were in ancient Israel. The number of deaths being recorded against Nigerians could be reduced in much the same way as it was done in ancient Israel. The way that Nigerians seek for solutions to the pandemic is similar to that of ancient Israel which makes the pericope potent in speaking anew in present times.

\section{Literary analysis of Numbers 12:9-16}

A close reading of the pericope establishes Moses as the highest of prophets in addition to being one who can look directly upon the likeness of God. The pericope is divided into four parts: vv. 9-12, vv.13-14, v.15 and v. 16. The first part deals with the pandemic. The second part explores transparent leadership. The third part concerns the isolation of the infected person. And the last part deals with the restoration and recovery. Miriam and Aaron's revolt against Moses (Numbers 12:1ff) sets the stage for the pandemic that befell the Israelites (Leon-Dufour 2004:1). This pericope was chosen because vv. 1-8 of Chapter 12 is concerned with the discussion between God, Moses and Miriam. From v.9, it discusses the calamity that befell Miriam, and indirectly the people of Israel. In vv. 9-12, there is a transparent and systematic profiling of the situation as it affects Israel. Miriam was stricken with leprosy. Leprosy was a disease involving bodily decay and corruption. It was not hidden from the people. Aaron, Moses and all the Israelites were able to identify that there was a crisis. The people of Israel, with Aaron at the forefront, sought measures to first heal Miriam and then protect the rest of the Israelites from infection. This part could be termed 'systematic profiling of the victims and environs'.

In vv. 13-14, there was a search for leadership in this moment of crisis. Moses stood up to the challenge. He strategised on how to solve the problem. But Moses was not glad because God punished Miriam. When Aaron asked Moses to help Miriam, Moses prayed to God for mercy and delivery of the sick, and also prayed to God to revoke the pandemic. It was a very short, but very sincere prayer. God answered Moses's prayer immediately. He called upon God to help them. This part could be termed 'in search of leadership during a crisis'. In v. 15, God advised that Miriam should be isolated and quarantined. This the people of Israel did. They shut Miriam from the camp for 7 days and there was a halt the movement of humans and animals. This part could be termed 'isolation, quarantine, and lockdown during the period of pandemic'. In v.16, Miriam is restored to health and her period of isolation is over. The period of lockdown for the Israelites was over. The people of Israel moved from Hezeroth and stayed in the wilderness of Paran. This part could be termed 'life after a crisis'. A closer reading of the pericope reveals the following:

\section{Systemic profiling of victims and their environment}

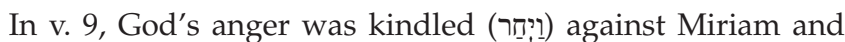
Aaron. Hebrew וַיִ (wayyihar [and he kindled]) indicates that the crisis was triggered by something. In this case, it was triggered by the anger (אֻ) of the Lord (Kohlenberger 1987:402). After God had convicted Miriam and Aaron for their sin, he sentenced them and suddenly withdrew (Siquans 2015:335). The result of the anger of the Lord was a crisis.

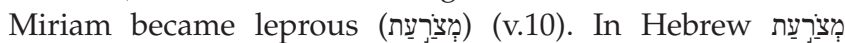
(məșōra 'aț) means 'to be struck with a skin disease' which, in the case of Miriam, was leprosy (Davidson 1970:510; Davies 1890:146; Robinson 1989:428). It was used in the Puah form to show that it was a harsh punishment. In v. 11, Aaron recognised the fact that it was an error on their part that caused the skin disease that infected Miriam. He identifies that for all known human pandemics, there is a cause. Aaron pleads on Miriam's behalf in vv. 11 and 12 and uses the term חָטָָאת ('guilt' or 'sin') to indicate that Miriam has indeed transgressed the norms governing the people of Israel. In v. 12, תְדֶי (tahî kammêt - let her not be as one dead) establishes transparent profiling of the identity of Miriam 
affected by the pandemic that befell Israel. In this case, the 'her' here was known to all Israelites to be Miriam.

\section{Leadership and collaboration during crisis}

In Numbers 12:13, there was the need for a good leader to manage the crisis. This was a crisis that could escalate if not carefully controlled. Now Aaron called Moses his master (attributed to Moses since he had the power to revoke Miriam's affliction). Aaron persuaded Moses to pray on Miriam's behalf (Cohen 1984:179). At this point, Aaron recognised the sovereignty of Moses above other Israelites and admitted his previous criticism as unreasonable. In v. 13, Moses rose during this period of crisis. Therefore Milgrom (1990b:93) exposes the uniqueness of Moses as the sole theme of the structure. Moses began a search for the solution by

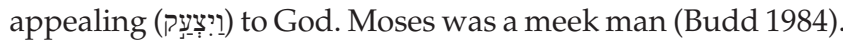

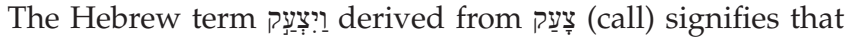
Moses immediately called out to God and raised a lamentation to God. Moses perceived that the root cause of the leprosy that afflicted Miriam was unimportant compared to the need for its containment. In v. 14, God advised Moses that the isolation of Miriam for 7 days was the only solution. God said

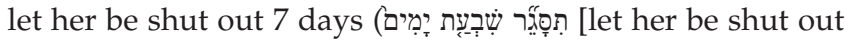
7 days]). The Hebrew term to shut herself in, to separate and to seclude herself from infecting other Israelites with her infectious disease. Miriam was isolated and separated from the rest of the Israelites for 7 days, and there was no further movement. The shutdown of Israel reveals that Israel shared in the pains of Miriam (Henry 1999:203). Israel showed commitment and empathy with Miriam's situation.

\section{Isolation, quarantine and lockdown}

Miriam was isolated and quarantined, and the nation of Israel was under lockdown. In v. 15, Miriam was (shut, isolated) from the healthy population and people stayed where they were (לְא נַָסָע camp for 7 days and the Israelites resumed their migration after her cure (Kohlenberger 1987:403). A close look at the entire book of Numbers, précised 5:1-4, states that lepers were left outside the camp to prevent them from infecting others with their disease. Miriam, with whom the pandemic began, was separated from the other Israelites and taken care of, but was not abandoned. This was a collaborative effort of both Moses and the people of Israel.

\section{Life after a crisis}

In Numbers 12:16, after the isolation of Miriam for 7 days, she was healed of this incurable disease. God did in fact, heal Miriam. This was based on the relationship and the value God placed on Moses above all Israel and its leaders (Mims 2017:4). If she were still a leper, she would not have been allowed to remain in the camp of Israel. Israel came together after this incident (אֵַָ) In the context of its usage, it tells us

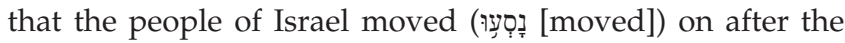
recovery of Miriam.
The pandemic that befell the Israelites in the wilderness of Sinai was severe and halted the movement of the Israelites. The only leader who could strategise and provide the roadmap for survival was Moses. Moses cried to God, and God insisted that Miriam must be isolated and quarantined. This commandment was what Moses followed in addition to the total lockdown on the movement of the Israelites. On the recovery of Miriam, after 7 days of shut down, the people of Israel moved from Hazeroth to the wilderness of Paran.

\section{COVID-19 pandemic in Nigeria}

On 25 February 2020, Nigeria recorded her first indexed case of the COVID-19 virus (declared by the Federal Ministry of Health on 27 February 2020). According to the Nigeria Centre for Disease Control, this index case is an Italian citizen who works in Nigeria and had returned from Milan, Italy to Lagos, Nigeria on the 25th of February 2020. In Nigeria, the Nigerian Centre for Disease Control (NCDC), the Presidential Task Force (PTF) on the COVID-19 virus and about 13 security agencies were empowered to manage the spread of the virus since March. Specifically, the NCDC was established in the year 2011 in response to the challenges of public health emergencies, and to enhance Nigeria's preparedness and response to epidemics through prevention, detection and control of communicable and non-communicable diseases.

The government of Nigeria took the COVID-19 pandemic with a pinch of salt. On 01 April 2020, Nigeria had 140 active confirmed cases, two deaths and nine recoveries. It was after this, that the government of Nigeria had to declare a 2-week shutdown. The declaration read (RFI 2020):

Based on the advice of the Federal Ministry of Health and the NCDC [Nigerian Centre for Disease Control], I am directing the cessation of all movements in Lagos and the FCT for an initial period of 14 days with effect from 11 pm on 30 March 2020. (p. 1)

Mbah reveals that Nigeria implemented a sweeping quarantine for three major states that are home to almost 30 million people in a bid to slow the spread of the new coronavirus in Africa's most populous country. These states are Lagos, Abuja and Ogun states. Other governors of the remaining 34 states in Nigeria, to protect their citizens, decided to shut down the civil service, schools and even markets. This was an attempt to stop the spread of the virus. However, hospitals, petrol stations and some markets were allowed to function because they are classified as essential services and products. As of 31 August 2020, there were over 53865 confirmed cases and 1013 deaths, which indicated that the numbers of infected persons and deaths are escalating.

\section{Leadership and collaboration in COVID-19 pandemic control}

The impacts of the coronavirus cannot be overemphasised. It has led to the insecurity of lives and property, increased poverty and domestic abuse. 
Insecurity: Firstly, this period of the coronavirus has brought an unprecedented increase in the crime rate in Nigeria. In Lagos, a group that is known as 'one million boys' has been busy during this period breaking into people's homes, threatening them and taking their property at gunpoint. In blatant disregard of the law the 'one million boys' would write letters to their victims saying 'the group threatened to carry out armed robbery attacks in some listed neighbourhoods' (Oyeleke 2020). Secondly, so many Nigerians have lost their lives during this period. Security operatives who were supposed to enforce the lockdown order and ensure the safety of Nigerians have killed many Nigerians for breaking the lockdown instruction. Table 1 shows cases of killings by security agencies in Nigeria.

Poverty: The level of poverty in Nigeria has increased enormously in recent times. Most Nigerians cannot afford food to eat. Most Nigerians have lost their jobs to the virus and have been thrown out of their houses because they could not pay their house rents. In fact, Nigerians are mired in hardships because of the failure of both the federal and state governments to come to the rescue of their citizens. The socio-economic impact of the pandemic has pushed many poor households to turn to desperate measures just to survive. Children face an increased risk of child labour, sexual exploitation and early marriages as families struggle to feed their families (ReliefWeb 2020). In times of this virus in Nigeria, $50 \%$ of the people live in poverty, $70 \%$ of the people do not have good drinking water; $23 \%$ are unemployed, $49 \%$ of the children are malnourished and $69 \%$ of the urban residents live in slum conditions (BBC 2020).

Domestic Abuse: Most Nigerians have been victims of domestic abuse. This is because they have nowhere to go and nobody to seek help from because of the lockdown in various parts of the country. On 20 April 2020, Mr. and Mrs. Fortune Stephens killed their maid Joy Okom Adole in their home at number 18 Ogundola Street, in the Bariga area of Lagos state (Ikeji 2020). Also, on 10 May 2020, in Lagos, Shade Moke allegedly killed her maid Halimat Sodiq, female, aged 16, over allegation of stealing her 2000 naira (News Agency of Nigeria 2020). These are all domestic abuses during the COVID-19 pandemic in Nigeria.

\section{Relevance of Numbers 12 to Nigeria in the period of the pandemic in Nigeria}

In the pericope, we witness the desert generation quest in fighting the pandemic that began with Miriam. We also see the possibilities and problems associated with fighting a pandemic and how leaders and people played their parts. Nigerians are currently involved in the fight against the coronavirus pandemic. The pericope provides us with some clues as to how to deal with pandemics.

Transparency in fighting the pandemic: the pericope reveals that the sick must be accounted for to avoid others getting unknowingly infected by the virus. There was transparency in the report that Miriam was terribly sick and all were instructed that no one should go near her during her period of isolation. It is likely that the plague of leprosy appeared on her face, and all those who saw her were struck by its appearance: she was leprous as snow, not only so white but so soft, the solid flesh losing its consistency, quite like what putrification does (Henry 1991:202). In Nigeria, there is a lack of transparency in the fight against the virus. When the first index case was confirmed in Nigeria, the government of Nigeria hid the identity of the Italian who had brought the virus, and this sad state of affairs continued. The identities of the people who had been tested and confirmed to have the virus were also hidden. There was no systematic profiling of the victims of the virus. This is why the number of people that have contracted the virus keeps increasing on a day to day basis. People who have had contacts with the carriers do not themselves know, and they keep spreading the virus unknowingly. In affirmation, carriers of the virus are moving around without knowing they harbour the virus and are consequently spreading it (Obinna 2020). This is because of the secrecy involved in profiling the victims of the virus.

A proactive leader is needed during a period of crises: the purpose of the story is to emphasise the supremacy of Moses (Snaith 1976:259). Moses rose to the occasion in the people's search for leadership during the period of crisis. Moses said, 'Heal her now, O Lord I beseech thee!' with a loud voice, because the veil that shrouded the symbol of God's presence was removed. Moses isolated Miriam from the rest of the

TABLE 1: Insecurity of lives by security agencies.

\begin{tabular}{llll}
\hline S/N & Insecurity issue & Date & Source \\
\hline 1 & $\begin{array}{l}\text { A young man, Joseph Pessu, was killed by army personnel } \\
\text { deployed to enforce a stay-at-home order in Delta State. }\end{array}$ & 02 April 2020 & $\begin{array}{l}\text { http://saharareporters.com/2020/04/02/army-kills-man-delta-over-stay- } \\
\text { home-order }\end{array}$ \\
2 & $\begin{array}{l}\text { Chidi Agwa-Arua at the weekend lost his life after being } \\
\text { shot by security forces }\end{array}$ & 04 April 2020 & $\begin{array}{l}\text { https://www.independent.ng/covid-19-one-dies-many-injured-as- } \\
\text { task-force-youths-clash-in-ebonyi/ } \\
\text { https://punchng-com/trigger-happy-policeman-kills-petrol-attendant-in- } \\
\text { abia-2/ }\end{array}$ \\
$\begin{array}{l}\text { A petrol attendant, Chibuisi Okameme, shot dead allegedly } \\
\text { by a policeman, Inspector Stanley Asu. }\end{array}$ & 05 April 2020 \\
$\begin{array}{l}\text { At least five people were killed and several others injured } \\
\text { at Kakuri and Trikania community in Kaduna South Local } \\
\text { Government Area of the state. }\end{array}$ & 06 April 2020 & $\begin{array}{l}\text { https://www.channelstv.com/2020/04/07/five-killed-in-kaduna- } \\
\text { as-security-operatives-enforce-lockdown-order/ }\end{array}$ \\
$\begin{array}{l}\text { The Anambra State Police Command has confirmed the } \\
\text { killing of two boys at Nkpor, near Onitsha }\end{array}$ & 15 April 2020 & $\begin{array}{l}\text { https://theeagleonline.com.ng/covid-19-lockdown-two-killed-as- } \\
\text { youth-pour-acid-on-policeman-in-anambra/ }\end{array}$ \\
\hline
\end{tabular}

$\mathrm{S} / \mathrm{N}$, serial number. 
Israelite population. He also imposed a lockdown in the camp. In the Nigerian context, there is no synergy in the fight against the pandemic. The authorities in charge of the fight against the virus include the PTF, the NCDC and 13 security agencies. Unfortunately, none of them could effectively coordinate the activities of these entities. Nobody has the sole charge of directing the activities of the various agencies fighting the coronavirus. The president would issue a directive that there should be no lockdown, the security agencies on the other hand, would be busy collecting bribes from commuters allowing free movement (Our Reporters 2020). Furthermore, whilst the PTF would be giving a breakdown in the number of cases of infected persons, the NCDC would mention some other figures. It is also sad to note that the NCDC, whose members are in charge of testing people, refused to test their own members to ensure that they are not contaminated. In fact, in Kogi State, Nigeria, the governor refused to allow NCDC officials into their state till they provided proof showing that their own members were free of the virus. Unfortunately, the NCDC members were not allowed to enter Kogi State. The officials of NCDC said they were not ready to be tested for COVID-19 and went back to Abuja (Taiwo 2020). This shows that there is a lack of leadership by example.

Civil disobedience to isolation, quarantine and lockdown: The pericope encouraged the isolation and quarantine of the infected and also enforced a lockdown of the area for the duration of the pandemic. Miriam's leprosy was limited to seven days and she would have to spend those many days outside the camp (v. 14) because she had an infectious skin disease that excluded her from the community of Israel (Num 5:2) (Hale \& Thorson 2006:354). The Jewish law demands that an infected person must observe the 7-day isolation (Snaith 1976:259). In Nigeria, the federal government and state governments placed restrictions on the movement of people from one state to the other. This was in a bid to curtail the transmission of the disease. Unfortunately, in Nigeria, the call for isolation and quarantine during the coronavirus crisis has been abandoned. Nigerians flout the government's call for a lockdown. Unlike Miriam in Numbers 12, Nigerians have continued to flout this order. Most Nigerians still go about their normal businesses notwithstanding the government directives. Unfortunately, even those who tested positive and were placed in isolation and quarantine ran away to unknown destinations (Table 2). The pericope reveals that after 7 days, Miriam was healed. The isolation of Miriam and the lockdown in Israel show that every citizen valued the proclamation. The importance of Miriam's role in the community is clear from the fact that the congregation did not move on from Hazeroth; not until she had been brought back into the camp (12:15) (Adeyemo 2006:185).

Social justice for everyone: During this period of crisis, leaders are supposed to treat everyone with equality, irrespective of ethnic, tribal or religious affiliations. Moses did not permit anyone to move, not even his family members. This was to show that all Israelites are equal in his and God's eye. Moses was meek, humble, and pious and God affirmed the uniqueness and superiority of Moses as a mediator of revelation (L'Heureux 2007:85). Unfortunately, in Nigeria, the federal government and most state governors began to play politics with the COVID-19 pandemic. The federal government who declared a shut down of the aviation industry in Nigeria since 19 March 2020 cunningly allowed some people from the Ivory Coast to come into Nigeria and Rivers state on 08 April 2020. The governor of River state got the report of this development through intelligence and arrested the immigrants. In defence, the federal government declared through Hadi Sirika, the minister of aviation, that the federal government had the right to allow anyone into the country. According to him (Jimoh \& Aliyu 2020):

Whether we gave approval for the flight, yes we did, and we did in national interest. All of those flights are for the purposes of improving the national revenue, to which Rivers State is the greatest beneficiary. (p. 1)

Sola lamented that for all practical purposes, the restrictions imposed by the federal government came quite late as numerous travellers from high-risk countries had been allowed access into the country, posing a great risk of widespread COVID-19 infection amongst Nigerians (Ogundipe 2020:1). Unfortunately, this was a period when the whole country was battling to save Nigerians from being infected. Furthermore, the Almajiri children in Kano state, of whom about 432 were tested, turned out to be COVID-19 infected. What the governor of Kano state did was to load these Almajiri children in a trailer and sent them to different

TABLE 2: Nigeria's COVID-19 patients who ran away from hospitals and refused to isolate themselves.

\begin{tabular}{|c|c|c|c|c|}
\hline$S / N$ & What happened & State & Date & Source \\
\hline 1. & $\begin{array}{l}\text { Ahmed threatened doctors and nurses at the isolation centre with a jack knife so } \\
\text { that he could walk out of the centre. The doctors and nurses had no choice but to } \\
\text { let him go. }\end{array}$ & Delta & 10 May 2020 & $\begin{array}{l}\text { https://www.vanguardngr.com/2020/05/naval-personnel- } \\
\text { allegedly-escapes-from-delta-covid-19-isolation-centre/ }\end{array}$ \\
\hline 2. & $\begin{array}{l}\text { The Kaduna State Ministry of Health has warned two persons who tested positive } \\
\text { for COVID-19 and ran away. }\end{array}$ & Kaduna & 08 May 2020 & $\begin{array}{l}\text { https://www.channelstv.com/2020/05/10/kaduna-govt- } \\
\text { declares-two-run-away-covid-19-patients-wanted/ }\end{array}$ \\
\hline 3. & $\begin{array}{l}\text { Six persons who returned to their hometown, Ejigbo, from the Ivory Coast with } \\
\text { confirmed infection of coronavirus escaped from isolation centre in Osun. }\end{array}$ & Osun & 03 April 2020 & $\begin{array}{l}\text { https://www.pmnewsnigeria.com/2020/04/04/breaking-six- } \\
\text { coronavirus-patients-escape-from-isolation-center/ }\end{array}$ \\
\hline 4. & $\begin{array}{l}\text { A commercial driver who has tested positive for COVID-19 has escaped from an } \\
\text { isolation centre in Bida. }\end{array}$ & Niger & 02 April 2020 & $\begin{array}{l}\text { https://www.radionigeria.gov.ng/2020/04/02/niger-govt- } \\
\text { denies-covid-19-escape-case/ }\end{array}$ \\
\hline 5 & $\begin{array}{l}\text { An unnamed } 25 \text {-year-old man, who was admitted at the Abubakar Tafawa Balewa } \\
\text { University Teaching Hospital isolation centre after he tested positive to the } \\
\text { COVID-19 virus suddenly disappeared. } \\
\text { In the same vein, a } 12 \text {-year-old Almaniri child, who tested positive to the new } \\
\text { coronavirus after he was repatriated from Kano, also found his way out of the } \\
\text { camp where he and over } 400 \text { others were placed in isolation. }\end{array}$ & Bauchi & 08 May 2020 & $\begin{array}{l}\text { https://standarddailytimes.com/news/bauchi-officials-go- } \\
\text { after-escaped-covid-19-patient/ }\end{array}$ \\
\hline
\end{tabular}

S/N, serial number; COVID-19, coronavirus disease 2019. 
states in Nigeria without notifying the administrative authorities of these states (Ugbor 2020). This is a case of I cannot die alone.

In order to stem the tide of escalating infections in Nigeria, the following recommendations are necessary:

- Miriam was known to all as the carrier of an infectious disease. There is a need for the federal government to be transparent in profiling individuals or families who are victims of the coronavirus infections. This will help others who may have had contact will them to self-isolate themselves to avoid infecting others.

- Moses, notwithstanding his family relationship with Miriam, ensured that she followed the Jewish law of isolation for people with communicable disease. Playing politics with the lives of the people does not make sense especially during the period of pandemics like the coronavirus in Nigeria. The federal government and state government of Nigeria should work together, and avoid bringing in sentiments, tribalism, party politics or even religion in the fight against the virus. There is a need for cooperation amongst all groups involved in the fight against the virus.

- The composition of the PTF on coronavirus should be revisited. It does not make sense that the composition of this team is made up of politicians who have little or no business in the medical line. Unfortunately, a look at the composition of this team reveals that no medical doctor, nurse, religious leader or psychologist is present in the team. This is why Nigerians believed that some shoddy deals are being carried out by PTF through the siphoning of monetary fund meant for the fight against the virus.

- All Israelites obeyed the lockdown imposed on them by their leader, Moses. Nigerians should also help themselves by obeying the lockdown. Through the lockdown, social distancing is achieved and cases of victims with the virus will be reduced drastically.

- This is the time for the rich to shower love on the poor. Those that have food should start sharing with friends, neighbours and relatives who they know are hungry at this point. This is a sign of love and unity in the period of crisis. Politicians and those with political ambition should also see this time as an opportunity to showcase their leadership skills by giving palliatives to the poor and the indigent ones.

Very importantly, in the period of crisis such as this health crisis, the people who are a part of the security agencies should be trained and sensitised on methods to carry out their job with civility.

\section{Conclusion}

Numbers 12:9-16 reveals that leadership and collaboration are needed in the fight against the coronavirus pandemic in Nigeria. The present crisis in Nigeria can be managed from the lens of the pericope. The increase in the level of coronavirus cases in Nigeria is due to the lack of transparency in profiling the people infected by coronavirus; inefficient leadership in crisis management and the lack of citizen's collaboration through civil disobedience. In the pericope, Moses displayed efficient leadership through the systematic profiling of the person who was infected, and the Israelites respected the policy of isolation, lockdown and quarantine as advised by Moses. Nigerian leaders are encouraged to engage in transparent and systematic profiling of victims of coronavirus, and the citizens should avoid flouting the government's directive on isolation and quarantine for infected people.

\section{Acknowledgements}

We sincerely thank members of AOSIS for their efforts in getting this work published.

\section{Competing interests}

The authors have declared that no competing interests exist.

\section{Authors' contributions}

F.C.U. and C.T.N. equally contributed to the design, implementation of the research, analysis of the results and to the writing of the manuscript.

\section{Ethical consideration}

This article followed all ethical standards for research without direct contact with human or animal subjects.

\section{Funding information}

This research received no specific grant from any funding agency in the public, commercial or not-for-profit sectors.

\section{Data availability statement}

Data sharing is not applicable to this article as no new data were created or analysed during this study.

\section{Disclaimer}

The views and opinions expressed in this article are those of the authors and do not necessarily reflect the official policy or position of any affiliated agency of the authors.

\section{References}

Adeyemo, T. (ed.), 2006, 'Numbers', in Africa Bible Commentary, p. 185, WorldAlive Publishers, Nairobi.

Alexander, T.D. \& Baker, D.W., 2003, Dictionary of the Old Testament Pentateuch, Intervarsity Press, Downers Grove, III.

Amaza, M., 2020, Nigerians are worried a Covid-19 catastrophe is unfolding in this ancient northern city, viewed 09 May 2020, from https://qz.com/africa/1853926/ nigerians-fear-a-covid-19-catastrophe-is-unfolding-in-kano/.

BBC, 2020, Coronavirus: Why some Nigerians are gloating about Covid-19, viewed 23 April 2020, from https://www.bbc.com/news/world-africa-52372737.

Bellinger, W.J., 2012, Leviticus, Numbers (Understanding the Bible Commentary Series), Baker Books, Grand Rapids, MI.

Boniface-Malle, A., 2006, 'Numbers', in T. Adeyemo (ed.), Africa Bible Commentary, p. 171, WordAlive Publishers, Nairobi.

Budd, P.J., 1984, 'Numbers', in D.A. Hubbard \& G.W. Barker (eds.), Word Biblical Commentary, vol. 5, p. xxv, Word Books, Waco, TX. 
Cohen, N.J., 1984, 'Miriam's song: A modern Midrashic reading', Judaism $33(2), 179$.

Coogan, M. (ed.), 2008, 'The Old Testament: A very short introduction', in "Festivals of the Lord": Ritual in ancient Israel, p. 65, Oxford University Press, New York, NY.

Davidson, B., 1970, The Analytical Hebrew and Chaldee Lexicon, Zondervan, Grand Rapids, MI.

Davies, T., 1890, 'Bible Leprosy', The Old and New Testament Student 11(3), 142-152. https://doi.org/10.1086/470564

Enyiocha, C., 2020, 14 More Almajiri children from Kano test positive for COVID-19 in Kaduna, viewed 02 May 2020, from https://www.channelstv.com/2020/05/02/
breaking-14-more-almajiri-children-from-kano-test-positive-for-covid-19-inkaduna/.

Folarin, S., 2020, 'Almajiris deported from Kano test positive for COVID-19 in Kaduna', The Punch, 27 April 2020, p.1.

Gieniusz, A., 2013, "As a miscarriage". The meaning and function of the metaphor in 1 Cor 15:1-11 in light of Num 12:12 (LXX)', The Biblical Annals 60(1), 93-1107.

Gould, T., 2005, A disease apart: Leprosy in the modern world, St. Martin's Press, New York, NY, p. 13.

Hale, T., 2007, The applied Old Testament Commentary, David C. Cook Distribution, Ontario, p. 355

Hale, T. \& Thorson, S., 2006, The applied Old Testament Commentary, David C. Cook, Colorado Springs, p. 354

Henry, M., 1991, Matthew Henry's Commentary on the whole Bible, Hendrickson Publishers, Peabody, MA, p. 202

Ikeji, L., 2020, Lagos couple arrested for the death of their housemaid. They claim she committed suicide, her family say she was beaten to death!, viewed 23 April 2020 from https://www.lindaikejisblog.com/2020/4/lagos-couple-arrested-for-thedeath-of-their-housemaid-they-claim-she-committed-suicide-her-family-say-shewas-beaten-to-death-photos.html.

Izundu, C.C., 2020, What is behind Nigeria's unexplained deaths in Kano?' viewed 28 April 2020, from https://www.bbc.com/news/world-africa-52454259.

Jimoh, A. \& Aliyu, A., 2020, 'Rivers: FG says Caverton pilots get flight approval', DailyTrust, 08 April, p. 1.

Kohlenberger III, J.R. (ed.), 1987, 'Numbers 12', in The interlinear NIV Hebrew-English Old Testament, Zonderan Publishing House, Grand Rapids, MI, p. 402-403.

Leon-Dufour, X., (2004). Dictionary of Biblical Theology, Burn \& Oates, London.

Lewis, G., 1987, 'A Lesson from Leviticus: Leprosy', Man 22(4), 593-612.

L'Heureux, C.H., 2007, 'Numbers', in R.E. Brown, J.A. Fitzmyer \& R.E. Murphy (eds.) The Jerome Biblical Commentary, Indira Printers, New Delhi, p. 85.

Mcewen, E.L., 1911, The Leprosy of the Bible: Its religious aspect, Loc cit, The Biblical World, pp. 255-261.

Milgrom, J, 1990a, The JPS Torah commentary - Numbers, The Jewish Publication Society, New York, NY, pp. 459-460.

Milgrom, J., 1990b, Numbers (The JPS Torah Commentary), The Jewish Publication Society, New York, NY, p. 93.

Mims, C.A., 2017, In the beginning: The Creation narrative, Bible Narratives LLC, Hampton, p. 4.

Ndjerareou, A., 2006, 'Exodus', in T. Adeyomo (ed.), African Bible commentary, WordAlive Publishers, Nairobi.
News Agency of Nigeria, 2020, Madam tortures 16-year-old maid to death over alleged theft of N2000, viewed 11 May 2020, from https://www.pulse.ng/news/metro/ madam-tortures-16-year-old-maid-to-death-over-alleged-theft-of-n2000/d5y0chl.

Nigeria Centre for Disease Control, 2020, About the NCDC, viewed 23 August 2020, from https://ncdc.gov.ng/ncdc.

Noth, M. (ed.), 1968, 'Numbers: A commentary', in Old Testament literature, p. 92 John Knox Press, Westminster.

Noth, M., 1972, A history of Pentateuchal traditions, Prentice Hall, Englewood Cliffs, NJ. Nwanze, C., 2019, 'History of the Almajiri system in Nigeria', The Guardian, 29 May, p. 1.

Obinna, C., 2020, Nigeria: Fears over COVID-19 patients without symptoms, viewed 10 May 2020, from https://allafrica.com/stories/202005100024.html.

Ogundipe, S., 2020, 'Gaps in Nigeria's COVID-19 response fuelling transmission of cases', Vanguard, 12 May, p. 1.

Our Reporters 2020, 'Ebonyi to prosecute security personnel caught collecting bribe', Vanguard, 03 April, p. 1.

Oyeleke, S., 2020, 'One million boys: We've joined forces with soldiers, others - Lagos police', The Punch, 18 April, p. 1.

ReliefWeb, 2020, COVID-19 set to impact hundreds of thousands of children in dangerous mix of poverty, hunger and protection risks, viewed 23 April 2020, from https://reliefweb.int/report/nigeria/covid-19-set-impact-hundreds-thousandschildren-dangerous-mix-poverty-hunger-and.

RFI, 2020, Nigeria orders Abuja, Lagos into coronavirus lockdown, viewed 30 April 2020, from http://www.rfi.fr/en/international/20200330-nigeria-orders-abujalagos-into-coronavirus-lockdown-sokoto-borders-closed-buhari-covid-19.

Robern, M., 2012, 'How do you solve a problem like Miriam? An exegesis of Numbers 12', in THB 3001: The Hebrew Bible in context by Professor Marvin Sweeney, viewed 13 April 2020, from http://bodilyintegrity.com/files/papers/RobernExegesis.pdf.

Robinson, B.P., 1989, 'The jealousy of Miriam: A note on Num 12', Zeitschrift für die alttestamentliche Wissenschaft [Journal of Old Testament scholarship] 101(3), 428.

Routledge, R., 2008, Old Testament Theology: A thematic approach, Inter-Varsity Press, Nottingham, p. 311.

Siquans, A., 2015, 'She dared to reprove her father': Miriam's image as a female prophet in Rabbinic interpretation', Journal of Ancient Judaism 6(3), 335-357. https://doi.org/10.30965/21967954-00603004

Snaith, N.H. (1976). 'Numbers', in M. Black \& H.H. Rowley (eds.), Peake's commentary on the Bible, Thomas Nelson and Sons Ltd, Nairobi, p. 259.

Taiwo, G., 2020, NCDC officials ran away from COVID-19 test in Kogi, says commissioner, viewed 08 May 2020, from https://www.thecable.ng/kogi-to-ncdcwhy-did-you-take-samples-of-doctors-from-china-but-rejected-covid-19-test-inour-state.

Tervanotko, H., 2020, How the ancient Israelites dealt with epidemics - The Bible tells of prophecy and rituals, viewed 13 April 2020, from https://theconversation.com/ how-the-ancient-israelites-dealt-with-epidemics-the-bible-tells-of-prophecy-andrituals-135803.

Tushima, C.T.A., 2018, 'Exchange of wife for social and food security: A famine refugee's strategy for survival (Gn 12:10-13:2)', HTS Teologiese Studies/ Theological Studies 74(1), a4769. https://doi.org/10.4102/hts.v74i1.4769

Ugbor, E., 2020, 'Anxiety in Abia, as security agents intercept truckload of Almajiris from North', Vanguard, 06 May, p. 1. 